Research Article

\title{
Evaluation of Hepatoprotective and in vivo Antioxidant Potentials of Methanol Extract of Tephrosia pumila against Thioacetamide Induced Liver Toxicity in Wistar Rats
}

\author{
Ramesh $C^{1}$, Pinkey Rawal' ${ }^{2}$ Soma Pramanik², Shabana $\mathrm{S}^{3}$ \\ ${ }^{2}$ Department of Pharmacology, East West College of Pharmacy, Bangalore, Karnataka, India. \\ ${ }^{2}$ Department of Pharmaceutical Chemistry, East West College of Pharmacy, Bangalore, Karnataka, India. \\ ${ }^{3}$ Department of Pharmacognosy, East West College of Pharmacy, Bangalore, Karnataka, India. \\ *Corresponding author's E-mail: rameshcology80@gmail.com
}

Received: 03-08-2021; Revised: 26-09-2021; Accepted: 05-10-2021; Published on: 15-10-2021. ABSTRACT

The objective of the current investigation was performed to assess the hepatoprotective potentials and in vivo antioxidant properties of methanol extract of Tephrosia pumila against thioacetamide induced liver damage in rats. The acute oral toxicity study of methanol extract was determined as per OECD guidelines and the extract was proved to be safe up to the dose of $2000 \mathrm{mg} / \mathrm{kg}$. The total duration of the study was 21 days and animals were divided into six groups. Hepatotoxicity was induced in the animals of all groups except normal control by single dose administration of Thioacetamide $(100 \mathrm{mg} / \mathrm{kg})$ at first day of the study followed by animals were treated daily with standard drug sylimarin and methanol extract of Tephrosia pumila $(100 \mathrm{mg} / \mathrm{kg}, 200 \mathrm{mg} / \mathrm{kg}$ and $400 \mathrm{mg} / \mathrm{kg})$ to respective groups for 21 days. Variations in biochemical parameters like alanine transferase (ALT), aspartate transferase (AST), alkaline phosphatase (ALP), total bilirubin, direct bilirubin, albumin, total protein, ions and others parameters like clotting time and weight of the liver were considered to determine beneficial effect of the extract. At the end of the study liver samples were collected and subjected to histopathological evaluation. There were significant variations in the above mentioned biochemical parameters in toxic control animals treated with Thioacetamide alone while in the animals treated with methanol extract and standard drug silymarin, all the parameters were normal possibly due to their beneficial property in protecting the liver against thioacetamide induced hepatotoxicity. The results obtained in the above study suggesting that, the methanol extract of Tephrosia pumila possess significant hepatoprotective activity.

Keywords: Hepatoprotective activity, Tephrosia pumila, Thioacetamide, ALT, AST and Bilirubin.

QUICK RESPONSE CODE $\rightarrow$

DOI:

10.47583/ijpsrr.2021.v70i02.028

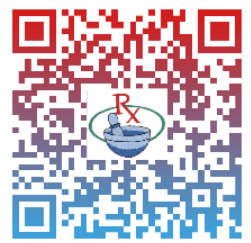

DOI link: http://dx.doi.org/10.47583/ijpsrr.2021.v70i02.028

\section{INTRODUCTION}

D ue to exposure of human life to various drugs, alcohol, toxins and viral infections, liver disorders have become one of the common health problems worldwide due ${ }^{1}$. Liver is vital organ of biliary system required to maintain important homeostasis of the body due its various responsibilities. The liver has got its own importance in the physiological system such as metabolism of ingested substances like carbohydrates, lipids, proteins, blood coagulation, detoxification process and immunomodulation are the primary functions of the liver ${ }^{1}$. The liver injury is associated with distortion of these metabolic functions 2 and results into disturbance in homeostasis of the body. But till now there is no truly satisfactory liver protective drug in the modern system of medicine which is effective and safe. Hence natural remedies from medicinal plants are considered to be effective and safe alternative drugs for the treatment of hepatotoxicity and a number of medicinal plants in
Ayurveda, the Indian system of medicine, are recommended for the treatment of liver disorders ${ }^{3}$. About 600 commercial preparations with claimed liver protecting activity are available all over the world. About 100 Indian medicinal plants belonging to 40 families are used for herbal formulation ${ }^{4}$. The Tephrosia pumila is native to India and it is medicinally important and used in traditional system for the treatment of liver ailments ${ }^{5}$. The Tephrosia pumila is commonly known as Shankhpushpi and used in ayurvedic system of medicine as memory enhancer, neuroprotective ${ }^{6}$ and treatment many ailments. The leaves of this plants contains alkaloids, flavonoids, tannins and phenols ${ }^{7}$ and scientifically proved for its anti-diabetic ${ }^{9}$ antiulcer ${ }^{6}$, anti-anxiety ${ }^{10}$, antioxidant ${ }^{11}$ and many other pharmacological activities. The phyto-constituents of plant leaves are capable of reducing liver toxicity due to their antioxidant properties but, the plant has not been scientifically investigated for evaluation of hepatoprotective activity ${ }^{11}$. In view of this, the present study was undertaken to investigate the hepatoprotective activity of methanol extracts of Tephrosia pumila (TPME) leaves against thioacetamide induced liver damage in rats.

\section{MATERIALS AND METHODS}

\section{Chemicals}

All the chemicals and reagents used in presnt study were of analytical grade. The hepatotoxin thioacetamide was 
procured from Sigma-aldrich chemcal Pvt. Ltd., Bangalore.) and standard drug Silymarin was obtained from Himalya dug company, Bangalore. (Nice chemicals Bangalore) and Estimation Kits for AST, ALT, ALP, serum bilirubins, Sodium, Potassium, glutathione peroxidase was obtained from SPAN diagnostics

\section{Preparation of plant extract}

The ariel parts of plant Tephrosia pumila Linn were collected in Sri Venkateswara university, Tirupati, Andhrapradesh and authenticated by Dr. Madhava Chetty, Department of Botany, Sri Venkateswara university, Tirupati, Andhrapradesh and authenticated by Dr. Madhava Chetty. The plant leaves were shade dried and powdered; the coarse powder was subjected to successive extraction with petroleum ether and methanol (70\%). Then marc was subjected to extraction using methanol as solvent ${ }^{12}$.

\section{Preliminary phytochemical studies}

The methanol extract of Tephrosia pumila was subjected to preliminary phytochemical investigation as per the procedure described by Khandelwal. Dragon Droff's reagent was used to detect presence of alkaloids. Neutral ferric chloride was used to detect phenolic compounds that appear in the form of blue spots. Folin Ciocalteau test and Fiegel' test was used to detect flavonoids and glycosides, respectively ${ }^{13,14}$.

\section{Animals}

Healthy adult Wistar rats weighing 180-200 was purchased from the Venkateswara Enterprises, Bangalore. The animals were housed in well ventilated cage and animals

\begin{tabular}{|c|c|c|}
\hline SI. No & Name of Group & Treatment \\
\hline $\mathbf{I}$ & Normal & Treated with normal saline $5 \mathrm{ml} / \mathrm{kg}$ i.p \\
\hline II & Toxic control & $\begin{array}{l}\text { Treated with Thioacetamide (TAA) }(100 \mathrm{mg} / \mathrm{kg}, \text { b. w., s.c.) as a } 2 \% \mathrm{w} / \mathrm{v} \text { solution } \\
\text { in water for injection on day } 1^{\text {st }} \text { and then vehicle for } 21 \text { days. }\end{array}$ \\
\hline III & Standard Control & $\begin{array}{l}\text { Treated with Thioacetamide (TAA) }(100 \mathrm{mg} / \mathrm{kg} \text { b. w., s.c.) as a } 2 \% \mathrm{w} / \mathrm{v} \text { solution in } \\
\text { water for injection on day } 1^{\text {st }} \text { and then silymarin }(25 \mathrm{mg} / \mathrm{kg} \text { per day, p. o.) for } 21 \\
\text { days. }\end{array}$ \\
\hline IV & TPME-100mg & $\begin{array}{l}\text { Treated with Thioacetamide (TAA) }(100 \mathrm{mg} / \mathrm{kg} \text { b.w., s.c.) as a } 2 \% \mathrm{w} / \mathrm{v} \text { solution in } \\
\text { water for injection on day } 1^{\text {st }} \text { and then methanol extract of low dose } \\
(100 \mathrm{mg} / \mathrm{kg} ., \mathrm{p} . \mathrm{o}) \text { of Tephrosia pumila for } 21 \text { days. }\end{array}$ \\
\hline $\mathbf{v}$ & TPME -200mg & $\begin{array}{l}\text { Treated with Thioacetamide (TAA) }(100 \mathrm{mg} / \mathrm{kg} \text { b.w., s.c.) as a } 2 \% \mathrm{w} / \mathrm{v} \text { solution in } \\
\text { water for injection on day } 1^{\text {st }} \text { and then methanol extract of medium dose } \\
(200 \mathrm{mg} / \mathrm{kg} ., \mathrm{p} . \mathrm{o}) \text { of Tephrosia pumila for } 21 \text { days. }\end{array}$ \\
\hline VI & TPME -400mg & $\begin{array}{l}\text { Treated with Thioacetamide (TAA) }(100 \mathrm{mg} / \mathrm{kg} \mathrm{b.w.,} \mathrm{s.c.)} \mathrm{as} \mathrm{a} 2 \% \mathrm{w} / \mathrm{v} \text { solution in } \\
\text { water for injection on day } 1^{\text {st }} \text { and then methanol extract of high dose } \\
(400 \mathrm{mg} / \mathrm{kg} ., \text { p.o) of Tephrosia pumila for } 21 \text { days. }\end{array}$ \\
\hline
\end{tabular}

After 21 days of experimental period blood sample had been collected individually for all the animals by retroorbital puncture method and estimated for Aspartate amino transferase, Alanine amino transferase, Alkaline Phosphatase, Total bilirubin, Total protein, Glutathione peroxidase, Sodium and Potassium. The clotting time was determined for blood samples by capillary tube method. $17,18,19$. Later all the animals were sacrificed by cervical had 12 hours day and night schedule with temperature between $28 \pm 2^{\circ} \mathrm{C}$. The animals were housed in large spacious hygienic cages during the course of the experimental period. The animals were allowed free access to standard laboratory pellets and drinking water ad libitum. The study protocol was approved by Institutional Animal Ethics Committee, IJAHSM (Ref.no. IJAHSM/IAEC/2014/03) with the permission from Committee for the Purpose of Control and Supervision of Experiments on Animals (CPCSEA), Ministry of Social Justice and Empowerment, Government of India.

\section{Determination of acute oral toxicity}

Acute oral toxicity of ethanol extracts of Tephrosia pumila (TPME) was done according to the OECD guidelines No.425. The overnight fasted mice were divided into four groups, each group consisting of three female animals. The methanol extract (TPME) of Tephrosia pumila was given at high dose $(2000 \mathrm{mg} / \mathrm{kg}$ b.w.) by gastric incubation with a syringe. After administration of the extract, the animal were observed continuously for the first two hours and at 24 hours to detect changes in behavioral responses and also for tremors, convulsion, salivation, diarrhea, lethargy, sleep, coma and also were monitored up to 14 days for the toxic symptoms and mortality ${ }^{15}$.

\section{Evaluation hepatoprotective activity}

Thioacetamide induced hepatotoxicity in rats model $[16,17,18]$ as used for evaluation of hepato-protective activity for the plant extracts. The experimental design was as follows: dislocation, liver samples were collected and the individual weights of the livers were estimated.

\section{Determination of antioxidant enzymes}

The liver samples were dissected out and washed using icecold saline solution. The pieces of liver samples were subjected to homogenization using tissue homogenizer with in 0.1M Tris- $\mathrm{Hcl}$ buffer (at $\mathrm{pH} 7.4$ ). The homogenate 
was centrifuged and collected supernatant solution was used for the determination of liver antioxidant enzymes such as Glutathione Peroxidase (GPX), Catalase Peroxidase (CAP), Glutathione S transferase (GST) and Glutathione reductase (GRD). The homogenate was also determined for activity of Lipid Peroxidation (LOP) in the liver.

\section{Histopathological evaluation}

At the end of research work, 2 animals from each group were sacrificed by euthanasia. After exsanguinations of the liver were removed immediately and washed with ice-cool saline. The liver samples were fixed with $10 \%$ formaldehyde, dehydrated in a graded series of alcohol, and embedded in paraffin wax before sectioning. The tissue was cut into sections approximately $5 \mu \mathrm{m}$ thick, dewaxed, and rehydrated. The sections were then stained with haematoxylin-eosin dye and studied for histopathological changes using a light microscope. Each sample was observed at a magnification of $100 \mathrm{X}$.

\section{Statistical analysis}

The data obtained from the study were subjected to statistical analysis by one way ANOVA followed by Turkey multiple comparisons test, and results were expressed in terms of Mean $\pm S E M$ values. Statistical analysis was performed using GraphPad prism.

\section{RESULTS \& DISCUSSION}

\section{Phytochemical investigation}

The methanol extract of Tephrosia pumila Linn. was subjected to different preliminary chemical tests to determine the chemical constituents present in the extracts. The results of study suggested that, methanol extract consist of alkaloids, flavonoids, tannins and phenolic compounds.

\section{Acute oral toxicity:}

The results of acute oral toxicity study suggested that the extract of Tephrosia pumila ie, TPME was safe up to $2000 \mathrm{mg} / \mathrm{kg}$. As per the above study, dose fixation was done and hence low dose was decided as $200 \mathrm{mg} / \mathrm{kg}$ and high dose was decided $400 \mathrm{mg} / \mathrm{kg}$ for the above extract.

\section{Evaluation of hepatoprotective activity}

The fungicidal drug Thioacetamide get converted into potent hepatotoxins sulfine and sulfene metabolites after biotransformation in liver by cytochrome P450 systems which and produce centrilobular necrosis of hepatic cells. Administration of a single large dose of thioacetamide $100 \mathrm{mg} / \mathrm{kg}$ is followed by degenerative changes in liver cells of rats leads to centrizonal necrosis. The pre-necrotic changes include loss of glycogen and acidophilic degeneration of cells in the central zone. The liver damage is always followed by disturbances in the several function of live such as metabolism of nutrients, storage functions, synthetic function, detoxification process and etc $20,21,22$. Administration of methanol extract of Tephrosia pumila has shown variations in various biochemical parameters in animals induced liver damage by thioacetamide as follows

\section{Effect of TPME on Serum Enzymes, Direct bilirubin \& Total bilirubin}

Storage of various serum enzymes like ALT, AST and ALP is one of the important functions of liver. ALT and AST transaminases that are involved in transamination reactions of various amino acids while alkaline Phosphatase (ALP) is isoenzyme synthesized mainly by liver and has important role in dephosphorylating of biomolecules. These enzymes are leaked into blood in hepatotoxicity due to liver parenchymal damage and hence their concentrations in serum found to be elevated 23,24 . Another very important role of liver is detoxification of bilirubin which is breakdown product of haem a iron component of hemoglobin. The bilirubin uptake by liver parenchyma cells from the blood and conjugates with glucuronic acid in presence of enzyme glucuronyl transferase. Later conjugated bilirubin gets excreted through bile. In liver toxicity total bilirubin and direct bilirubin concentration are increased in serum due to reduced ability of liver parenchymal cells ${ }^{25}$.

In the present study, the serum enzymes ALT, AST and ALP and bilirubins were significantly $(P<0.001)$ elevated in toxic control group due to administration of Thioacetamide compare to animals of normal group as a result liver damage while TPME $(200 \mathrm{mg} / \mathrm{kg}$ and $400 \mathrm{mg} / \mathrm{kg})$ and standard drug silymarin significantly $(P<0.001)$ reduced concentration serum enzymes in therapeutic animals. The effect of methanol extract was comparable standard drug and it was dose. Treatment with silymarin and methanol extract significantly reduced serum concentrations of enzymes ALT, AST and ALP indicating the enhanced storage function and also reduced bilirubin levels in blood shows the increased detoxification in therapeutic animals compared to toxic group which could be due to possible protection given by methanol extract. (see Table No: 1 ).

\section{Effect of TPME on Total protein and Albumin}

Serum total protein, also called as total protein or plasma total protein is synthesized by the liver and is a important biochemical test for assessing liver function. The albumin and globulin that are produced in liver are the main components of total protein in the plasma ${ }^{26}$. In drug induced liver toxicity leads to reduction in total protein is observed due decreased albumin synthesis due to cirrhosis. In the present study, in toxic control group animals administered with thioacetamide, significant reduction of serum total protein and albumin was observed due to liver damage compared to normal animals but administration of silymarin and TPME $(200 \mathrm{mg} / \mathrm{kg}$ and $400 \mathrm{mg} / \mathrm{kg}$ ) caused dose dependent significant $(P<0.001)$ rise in total protein and albumin therapeutic group compared to toxic animals and the results. The results indicated the ability of methanol extract to reverse the hepatic damage caused by thioacetamide. (see Table No: 2). 


\section{Effect of TPME on serum ions}

The two main complications of hepatotoxicity are ascites and edem which are due to accumulation of fluids in extravascular sites of the body. In these complications serum ions sodium, potassium and chlorides moves of blood into extravascular tissues and hence finally lead to reduction in these ionic concentrations in blood [26]. In our study, there was significant reduction serum ionic concentration was observed in toxic control animals when compared to animals of normal group but serum ionic concentrations were significantly $(P<0.001)$ increased in animals of therapeutic groups treated with silymarin and TPME $(200 \mathrm{mg} / \mathrm{kg}$ and $400 \mathrm{mg} / \mathrm{kg})$ when compared to toxic animals. The effect of extract was dose dependent and comparable to standard. The methanol extract and sylimarin exhibited significant increase of ions sodium, potassium and chlorides which shows property of the methanol extract to reduce ascites and odema may be by regenerating the liver cells. (see Table No: 2 )

\section{Effect of TPME on liver weight}

The disturbance in the metabolism of carbohydrates, fats and proteins is main consequence of liver toxicity which leads to fatty change or fatty characterized by the deposition of fat in liver. Hence the total weight of liver increases due to the deposition of fat and triglycerides in drug induced hepatic damage [26]. In the present study, the serum enzymes ALT, AST and ALP were significantly $(P<0.001)$ elevated toxic control group due to administration of Thioacetamide compare to animals of normal group as a result liver damage while TPME $(200 \mathrm{mg} / \mathrm{kg}$ and $400 \mathrm{mg} / \mathrm{kg}$ ) and standard drug silymarin significantly $(\mathrm{P}<0.001)$ reduced concentration serum enzymes in therapeutic animals. The effect of methanol extract was comparable standard drug and it was dose. Administration of methanol extract and silymarin could able to normalize weight of livers in therapeutic groups indicates their liver protective properties (see Table No: 3 ).

Table 1: Effect of methanol extracts of Tephrosia pumila on serum enzymes and bilirubin against thioacetamide induced hepatotoxicity in rats

\begin{tabular}{|c|c|c|c|c|c|}
\hline \multirow{2}{*}{ Treatment } & \multicolumn{5}{|c|}{ Serum parameters } \\
\hline & ALT (IU/ml) & AST (IU/ml) & ALP (IU/ml) & Direct Bilirubin & Total Bilirubin \\
\hline Normal Control & $62.35 \pm 2.342$ & $129.8 \pm 2.467$ & $78.53 \pm 2.170$ & $0.02633 \pm 0.001026$ & $0.3453 \pm 0.01345$ \\
\hline Toxic Control & $151.9^{+++} \pm 1.302$ & $237.6^{+++} \pm 5.781$ & $207.1^{+++} \pm 6.816$ & $0.3128^{+++} \pm 0.007989$ & $0.8413^{+++} \pm 0.01963$ \\
\hline $\begin{array}{l}\text { Standard } \\
\text { (Silymarin) }\end{array}$ & $63.0 * * * \pm 3.543$ & $129.0 * * * \pm 3.233$ & $85.33 * * * \pm 3.299$ & $0.0752 * * * \pm 0.005977$ & $0.3738 * * * \pm 0.01314$ \\
\hline TPME $100 \mathrm{mg} / \mathrm{kg}$ & $148.8 \pm 1.103$ & $218.7 \pm 5.248$ & $198.4 \pm 4.445$ & $0.2450 \pm 0.01266$ & $0.8197 \pm 0.02382$ \\
\hline TPME 200 mg/kg & $133.3^{* *} \pm 1.272$ & $187.0 * * \pm 5.387$ & $132.4^{* * * *} \pm 2.424$ & $0.1655 \pm 0.003394$ & $0.6205^{* *} \pm 0.01817$ \\
\hline TPME 400 mg/kg & $88.59 * * * \pm 1.348$ & $135.9 * * * \pm 4.753$ & $85.24 * * * \pm 3.400$ & $0.07268 * * * \pm 0.004685$ & $0.3718^{* * *} \pm 0.01982$ \\
\hline
\end{tabular}

Values are mean \pm S.E.M, $n=6$ symbols represent statistical significance.

${ }^{n s} \mathrm{p}>0.05, * p<0.05, * * p<0.01, * * * p<0.001$ vs toxic control.

${ }^{n s} p>0.05,{ }^{+} p<0.05,{ }^{++} p<0.01,{ }^{+++} p<0.001$ toxic control vs normal control.

Table 2: Effect of methanol extracts of Tephrosia pumila on serum albumin, total proteins and ions against thioacetamide induced hepatotoxicity in rats

\begin{tabular}{|c|c|c|c|c|c|}
\hline \multirow{2}{*}{ Treatment } & \multicolumn{5}{|c|}{ Serum parameters } \\
\hline Normal Control & $4.690 \pm 0.07358$ & $5.367 \pm 0.1175$ & $138.2 \pm 0.8504$ & $5.065 \pm 0.1428$ & $77.43 \pm 1.125$ \\
\hline Toxic Control & $2.390^{+++} \pm 0.1241$ & $2.757^{+++} \pm 0.09793$ & $77.05^{+++} \pm 2.078$ & $2.237^{+++} \pm 0.07632$ & $137.0^{+++} \pm 0.9558$ \\
\hline $\begin{array}{c}\text { Standard } \\
\text { (Sylimarin) }\end{array}$ & $4.538^{* * *} \pm 0.1914$ & $5.230^{* * *} \pm 0.04712$ & $142.0^{* * *} \pm 2.488$ & $5.007^{* * *} \pm 0.1126$ & $80.35^{* * *} \pm 1.431$ \\
\hline TPME $\mathbf{1 0 0} \mathbf{~ m g} / \mathbf{k g}$ & $2.458 \pm 0.05902$ & $3.485 \pm 0.2593$ & $71.56 \pm 2.815$ & $2.228 \pm 0.04438$ & $130.6 \pm 2.017$ \\
\hline TPME $\mathbf{2 0 0} \mathbf{~ m g} / \mathbf{k g}$ & $3.432 * * \pm 0.1372$ & $3.922^{* *} \pm 0.1199$ & $79.00^{* *} \pm 0.7882$ & $3.178^{* *} \pm 0.07596$ & $111.9 * * \pm 1.675$ \\
\hline TPME $\mathbf{4 0 0} \mathbf{~ m g} / \mathbf{k g}$ & $4.635^{* * *} \pm 0.1692$ & $4.905^{* * *} \pm 0.07945$ & $78.31^{* * *} \pm 1.156$ & $4.723^{* * * \pm 0.06339}$ & $86.57^{* * *} \pm 4.027$ \\
\hline
\end{tabular}

Values are mean \pm S.E.M, $n=6$ symbols represent statistical significance.

${ }^{n s} p>0.05, * p<0.05, * * p<0.01, * * * p<0.001$ vs toxic control.

${ }^{n s} p>0.05,{ }^{+} p<0.05,{ }^{++} p<0.01,{ }^{+++} p<0.001$ toxic control vs normal control. 


\section{Effect of TPME on Clotting time}

The liver produces all the clotting factors associated with blood clotting mechanism and it has main role in regulating normal prothrombin time or clotting time. In liver disorders synthesis of clotting factors will be affected and hence clotting time is prolonged [25]. In our esteemed study, the prothrombin time was prolonged due to deficiency of clotting factors toxic animals compared to normal group as a result of thioacetamide induced liver injury. The dose dependent significant $(P<0.001)$ reduction in clotting time was observed animals treated with standard sylimarin while TPME $(200 \mathrm{mg} / \mathrm{kg}$ and $400 \mathrm{mg} / \mathrm{kg})$ which indicates methanol extract can reverse complications of hepatotoxicity (see Table No: 3 ).

\section{Liver antioxidant enzymes}

The ability of the living system to counteract free radical mediated damages is natural antioxidant mechanism in which glutathione Peroxidase, Catalase Peroxidase, Glutathione S transferase, glutathione reductase and Lipid peroxidase are produced in the affected organ/tissue. In the present study, there was found to be significant $(P<0.001)$ reduction concentration of liver antioxidant enzymes GPX, CAP,SOD, GSD and GRD in toxic control animals treated with Thioacetamide alone compare to normal animals. While animals of therapeutic groups treated with sylimarin and TPME $(200 \mathrm{mg} / \mathrm{kg}$ and 400 $\mathrm{mg} / \mathrm{kg})$, have exhibited significant $(\mathrm{P}<0.001)$ rise in liver antioxidant enzyme compare to toxic animals. This effect also indicating its potential to protect the liver cells against thioacetamide induced free radical damage (See Table No.4).

Table 3: Effect of methanol extracts of Tephrosia pumila on Liver weights and clotting time against thioacetamide induced hepatotoxicity in rats

\begin{tabular}{|c|c|c|}
\hline Treatment & $\begin{array}{c}\text { Liver weight } \\
\text { (gms) }\end{array}$ & Clotting Time \\
\hline $\begin{array}{c}\text { Normal } \\
\text { Control }\end{array}$ & $5.963 \pm 0.07504$ & $191.2 \pm 7.087$ \\
\hline $\begin{array}{c}\text { Toxic Control } \\
\text { Standard } \\
\text { (Silymarin) }\end{array}$ & $8.395^{+++} \pm 0.09691$ & $506.5^{+++} \pm 15.73$ \\
\hline $\begin{array}{c}\text { TPME 100 } \\
\text { mg/kg }\end{array}$ & $6.017^{* * *} \pm 0.1334$ & $191.3^{* * *} \pm 5.737$ \\
\hline $\begin{array}{c}\text { TPME 200 } \\
\text { mg/kg }\end{array}$ & $7.090 \pm 0.08595$ & $477.5 \pm 10.54$ \\
\hline $\begin{array}{c}\text { TPME 400 } \\
\text { mg/kg }\end{array}$ & $7.037^{* * *} \pm 0.1724$ & $229.3^{* * *} \pm 5.578$ \\
\hline
\end{tabular}

Values are mean \pm S.E.M, $n=6$ symbols represent statistical significance. ${ }^{n s} \mathrm{p}>0.05,{ }^{*} \mathrm{p}<0.05,{ }^{* *} \mathrm{p}<0.01,{ }^{* * *} \mathrm{p}<0.001$ vs toxic control.

${ }^{n s} p>0.05,{ }^{+} p<0.05,{ }^{++} p<0.01,{ }^{+++} p<0.001$ toxic control vs normal control.

Table 4: Effect of methanol extracts of Tephrosia pumila on liver antioxidant enzymes and lipid peroxidase against Thioacetamide induced hepatotoxicity in rats

\begin{tabular}{|c|c|c|c|c|c|c|}
\hline \multirow{2}{*}{ Treatment } & \multicolumn{6}{|c|}{ Liver Enzymes } \\
\hline & GPX (mg/G) & CAP (mg/G) & SOD (mg/G) & GST (mg/G) & GRD (mg/G) & LOP (mg/G) \\
\hline $\begin{array}{l}\text { Normal } \\
\text { Control }\end{array}$ & $8.958 \pm 0.2643$ & $58.18 \pm 2.015$ & $9.351 \pm 1.0210$ & $7.092 \pm 0.4456$ & $4.045 \pm 0.3952$ & $7.490 \pm 0.1897$ \\
\hline Toxic Control & $4.757^{+++} \pm 0.2648$ & $30.70^{+++} \pm 1.445$ & $5.467^{+++} \pm 1.411$ & $3.438^{+++} \pm 0.2230$ & $2.233^{+++} \pm 0.2441$ & $17.06^{+++} \pm 0.4039$ \\
\hline $\begin{array}{c}\text { Standard } \\
\text { (Sylimarine) }\end{array}$ & $8.132 * * * \pm 0.3254$ & $50.17 * * * \pm 1.118$ & $8.661^{* * * \pm 1.334}$ & $6.568 * * * \pm 0.4929$ & $3.852 * * * \pm 0.2376$ & $10.11^{* * * \pm 0.2847}$ \\
\hline $\begin{array}{l}\text { TPME } 100 \\
\mathrm{mg} / \mathrm{kg}\end{array}$ & $4.293 \pm 0.1515$ & $32.20 \pm 2.822$ & $5.618 \pm 2.641$ & $3.410 \pm 0.2276$ & $2.603 \pm 0.2976$ & $16.16 \pm 0.3766$ \\
\hline $\begin{array}{l}\text { TPME } 200 \\
\mathrm{mg} / \mathrm{kg}\end{array}$ & $5.890 * * \pm 0.08873$ & $36.58^{* *} \pm 2.828$ & $6.854^{* *} \pm 1.551$ & $5.027^{* *} \pm 0.1622$ & $3.642 * * \pm 0.5280$ & $13.56^{* *} \pm 0.4880$ \\
\hline $\begin{array}{l}\text { TPME } 400 \\
\mathrm{mg} / \mathrm{kg}\end{array}$ & $7.048^{* * * \pm 0.1978}$ & $49.64 * * * \pm 2.024$ & $8.650 * * * \pm 1.285$ & $6.300 * * * \pm 0.3416$ & $4.867 * * * \pm 0.4385$ & $10.77^{* * *} \pm 0.4058$ \\
\hline
\end{tabular}

Values are mean \pm S.E.M, $n=6$ symbols represent statistical significance. ${ }^{n s} p>0.05,{ }^{*} p<0.05, * * p<0.01, * * * p<0.001$ vs toxic control. ns $p>0.05,{ }^{+} p<0.05,{ }^{++} p<0.01,{ }^{+++} p<0.001$ toxic control vs normal control.

\section{Effect of TPME on Lipid peroxidase}

The lipid peroxidation is the another consequence of cell injury caused by the free radicals characterized by the increased lipid peroxidase (LOP) in the tissue. In the present study, lipid peroxidase level was significantly $(P<0.001)$ raised the concentration of lipid peroxidase (LOP)by the administration in toxic control animals compared to normal group. But the administration of reference standard silymarin and medium and high dose of TPME $(200 \mathrm{mg} / \mathrm{kg}$ and $400 \mathrm{mg} / \mathrm{kg})$ could reduce the level of lipid peroxidase in therapeutic groups compared to animals of normal toxic group (see Table No: 4).

\section{Histopathological evaluation}

The administration of thioacetamide was caused the complete loss of the normal architecture of livers in positive control animals with the appearance of 
vacuolated hepatocytes and degenerated nuclei. The pathological changes like vacuolization, fatty degenerations and coagulative necrosis of liver cells were found to be severe in the centrilobular region. The hepatotoxic metabolite thioacetamide produced excessive formation and deposition of fibrous tissue and results in development of scars. The nodular transformation of rat liver treated with TPME $100 \mathrm{mg} / \mathrm{kg}$ has shown, large septa of fibrous tissue flowing together which penetrated into the parenchyma cells were found. But sections of liver samples belong to therapeutic groups treated with high doses of methanol extract showed almost normal lobular pattern with tiny and a mild degree of fatty degenerations, necrosis and infiltration of lymphocyte which was more or less comparable to the standard drug silymarin treated groups (See Figure No. 1 to Figure No.5).

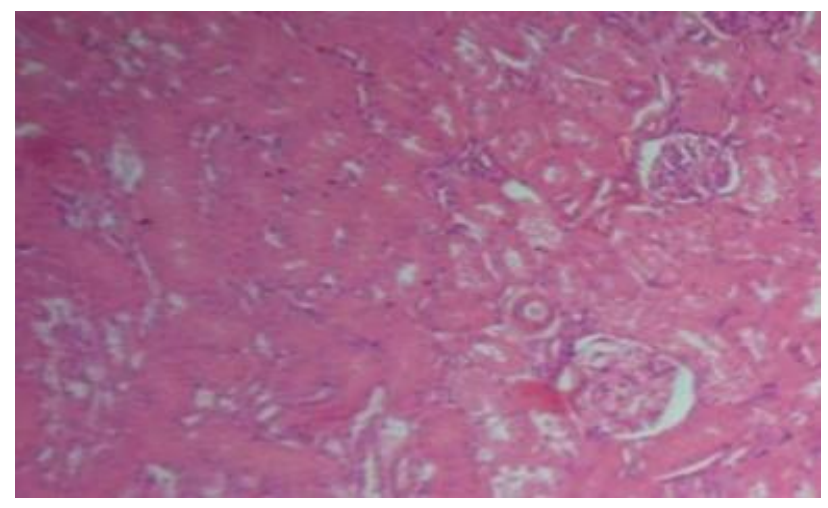

Figure 1: Histopathology of liver

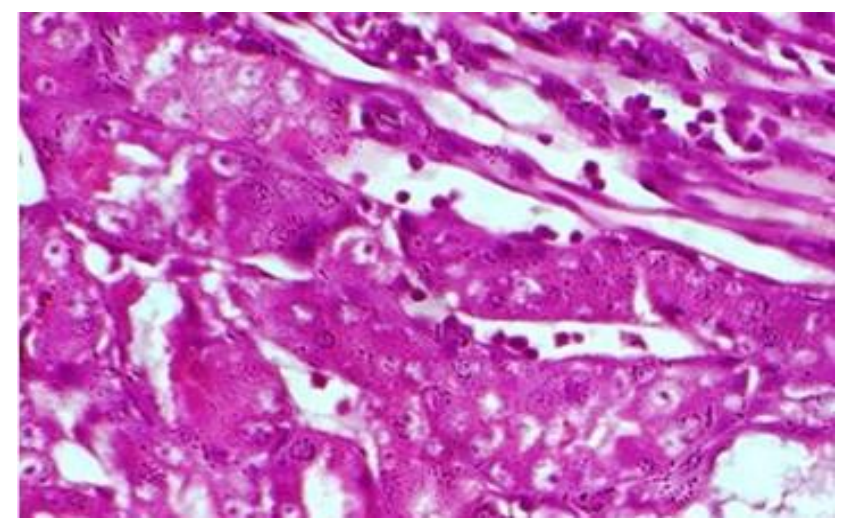

Figure 2: Histopathology of liver sample from Normal group sample from Toxic group

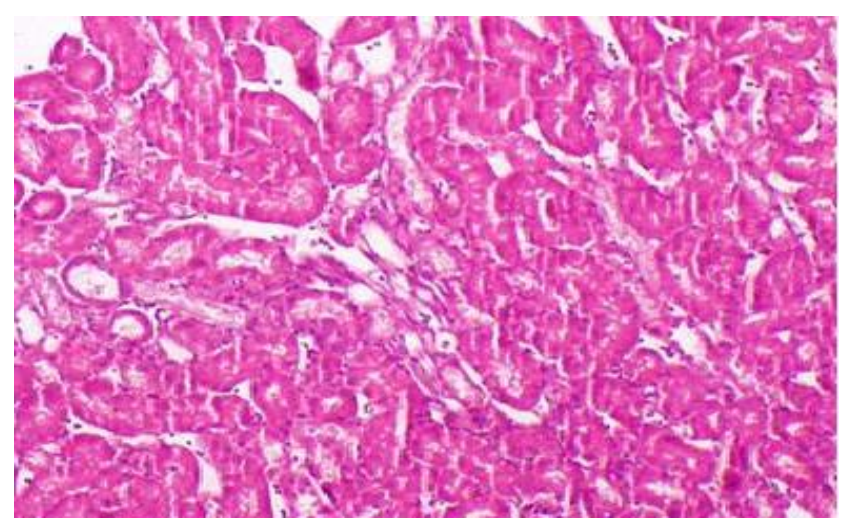

Figure 3: Histopathology of liver

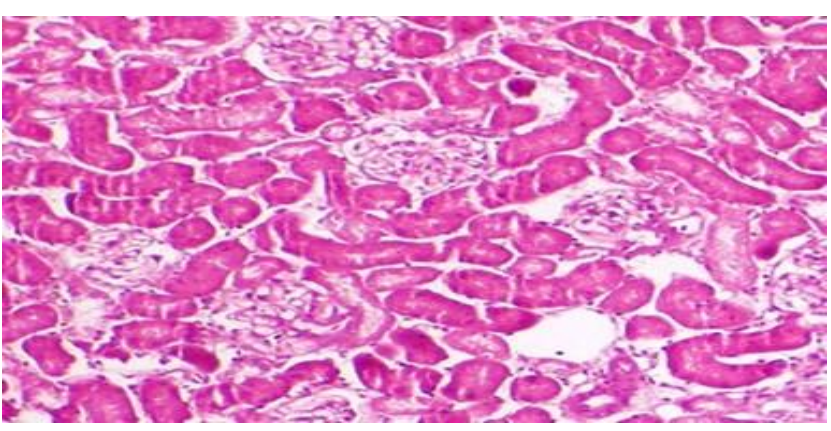

Figure 4: Histopathology of liver sample sample from standard group from TPME $(200 \mathrm{mg} / \mathrm{kg})$

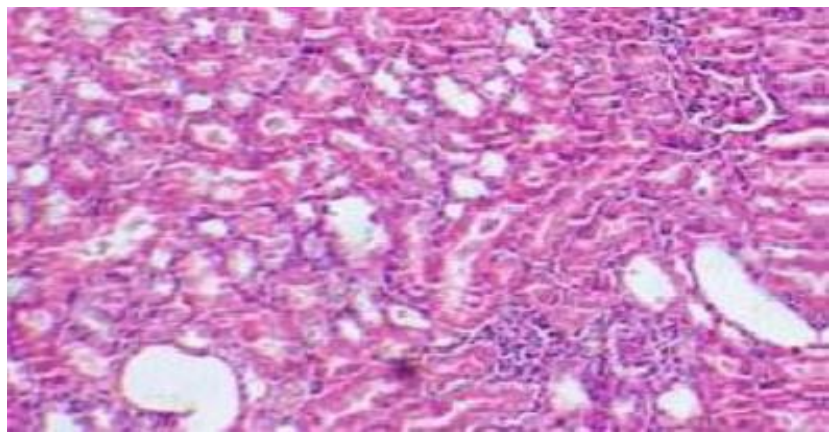

Figure 5: Histopathology of liver sample from TPME (400mg/kg)

The drug induced hepatotoxicity is mainly due to oxidative stress and free radicals mediated damage [22]. Hence free radical scavenging and antioxidant mechanisms are more important to reverse or prevent drug induced liver toxicity. The extracts of Tephrosia pumila had been reported for its antioxidant activity. In the present study methanol extract of Tephrosia pumila could reduce the most of the complications of thioacetamide induced hepatotoxicity and also significantly increased liver antioxidant enzymes such as glutathione Peroxidase, Catalase Peroxidase, Glutathione S transferase, glutathione reductase and lipid peroxidase which may be the possible mechanism of action of extract. Further studies are required to correlate the hepatoprotective potentials of the extract with increased glutathione concentrations and also to isolate and evaluate hepatoprotective principls from the methanol extract [26]. Hence in conclusion, the possible mechanism of beneficial liver protecting property of our extract due to its potent antioxidant activity. The Histopathological studies supported the results of biochemical tests, showing less damage in the cytoarchitecture of the liver.

\section{CONCLUSION}

The data obtained from estimation of biochemical parameters suggesting that, methanol extract of Tephrosia pumila leaves posses significant hepatoprotective property in thioacetamide induced liver toxicity in rat model.

Acknowledgements: The authors of manuscript are thankful to The principal and management of East West College of Pharmacy, Bangalore for providing facilities to conduct this research work.

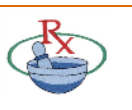




\section{REFERENCES}

1. Rajesh MG, Latha MS. Preliminary evaluation of the antihepatotoxic activity of Kamilari, a polyherbal formulation. J Ethnopharmacol 2004; 91: 99-104.

2. Ramachandra SS, Absar AQ, Viswanath Swamy AHM, Tushar PPT, Prabhu K, Veeran GA. Hepatoprotective activity of Calotropis procera flowers against paracetamol-induced hepatic injury in rats. Fitoterapia 2007; 8: 451-4.

3. Subramaniam A, Pushpangadan P. Development of Phytomedicine for liver disease. Ind J Pharmacol 1999; 31: 166-75.

4. Bahar A, Tanveer A, Shah AK. Hepatoprotective activity of Luffa echinata fruits. J Ethnopharmacol 2001; 76: 187-9.

5. Yoganarasimhan SN. Medicinal Plants of India; 2: 30-1

6. Neeraj kumar S, Alok N, Srihari M and Vinod kumar D. An update on shankhpushpi, a cogntition-boosting ayurvedic medicine. J chin.integr.med 2009; 7(11): 1001-22.

7. Gholap and Kar A. Hypoglycaemic effects of some plant extracts are possibly mediated through inhibition in corticosteroid concentration. An Int. J Pharm.Sci 2004; 59: 876-8.

8. Anxiolytic activity of Convolvulus pluricaulis. Obtained from: http://michaelmazur.net/xml.php

9. Sairam K, Rao CV and Goel RK. Effect of Convolvulus pluricaulis Chois on gastric ulceration and secretion in rats. Ind. J Exp.Biol 2001; 39(4): 350-4.

10. Alok Nahata, Patil UK and Dixit VK. Anxiolytic activity of Evolvulus alsinoides and Convulvulus pluricaulis in rodents. 2009; 47(5): 444-51.

11. Prasad SB and Sharma A. Antioxidant activity of Convolvus plauricalis. Invent.rapid:Plant act 2011; 79(11):18-24.

12. Kokate CK. Practical Pharmacognosy. New Delhi, Vallabh Prakashan 1994;4:110-1.

13. Trease GE., Evans MC. Text book of Pharmacognosy London, BailliareTindall;1983; 12: 193, 336.

14. Khandelwal KR, Practical Pharmacognosy-techniques and experiments. Pune; Nirali Prakashan; 2000.
15. OECD 2001-gudeline on acute oral toxicity (AOT) Environmental health and safety. 2001.

16. Aftab A, Pillai KK, Abul KN, Shibli JA and Pal SN. Evaluation of hepatoprotective potential of jigrine post-treatment against thioacetamide induced hepatic damage. J Ethnopharmacology 2002; 79: 35-41.

17. Monograph series on testing and adjustment No.423. Aftab A, Pillai KK, Abul KN, Shibli JA, Pal SN, Balani DK. Evaluation of hepatoprotective potential of jigrine post-treatment against thioacetamide induced hepatic damage. J Ethnopharmacol 2002; 79: 35-41.

18. Kumar G, Sharmila Banu G, Vanitha Pappa P, Sundararajan M, Rajasekara Pandian M. Hepatoprotective activity of Trianthema portulacastrum L. against paracetamol and thioacetamide intoxication in albino rats. J Ethnopharmacol 2004; 92: 37-40.

19. Kamlesh S, Nisha S, Anish C, Ashish M. In vivo antioxidant and hepatoprotective activity of methanolic extracts of Daucus carota seeds in experimental animals. Asian Pac J of Trop Biomed 2012; 385-8

20. Fan Sabrina, Weng Ching-Feng. Co-administration of Cyclosporine Alleviates thioacetamide induced liver injury, World J Gastroenterol 2005; 11: 1411-19.

21. Shashi K, Ramaiah, Apte U, Mehendale HM. Cytochrome P4502E1 induction increases thioacetamide liver injury in diet restricted rats. Drug Meta Dispo 2001; 29: 1088-95.

22. Shapiro H, Ashkenazi M, Weizman N, Shahmurov M, Aeed H, Bruck R, Curcumin ameliorates acute thioacetamide induced hepatotoxicity. J Gastroenterol Hepatol 2006; 21: 358-66.

23. Harshmohan. The liver, biliary tract, exocrine and pancreas: Textbook of Pathology. 4th ed. New Delhi: Jaypee Brothers Medical Publishers (P) Ltd 2002: 22-4, 569-80.

24. Aftab A, Pillai KK, Abul KN, Shibli JA, Pal SN, Balani DK. Evaluation of hepatoprotective potential of jigrine posttreatment against thioacetamide induced hepatic damage. J Ethnopharmacol 2002; 79: 35-41.

25. Satyanarayana $U$, Chalrapani. Liver function tests. Fundamentals of biochemistry Kolkata; 2006: 453-8.

26. Barry hallwll, Jonh MC. Free radicals in biology and medicine: Gutteridge protection against free radical damage. 2 nd ed. Oxford: Clarendon press; 1989: 334-9.

Source of Support: The author(s) received no financial support for the research, authorship, and/or publication of this article.

Conflict of Interest: The author(s) declared no potential conflicts of interest with respect to the research, authorship, and/or publication of this article.

For any question relates to this article, please reach us at: editor@globalresearchonline.net New manuscripts for publication can be submitted at: submit@globalresearchonline.net and submit_ijpsrr@rediffmail.com 